\title{
EPSL
}

\section{Mechanical (de-)coupling of the lithosphere in the Valencia Trough (NW Mediterranean): what does it mean?}

\author{
J.M. Gaspar-Escribano ${ }^{\mathrm{a}, *}$, M. ter Voorde $^{\mathrm{a}}$, E. Roca ${ }^{\mathrm{b}}$, S. Cloetingh ${ }^{\mathrm{a}}$ \\ a Faculty of Earth and Life Sciences, Vrije Universiteit, De Boelelaan 1085, 1081 HV Amsterdam, The Netherlands \\ b Facultat de Geologia, Universitat de Barcelona, c/Martí Franqués s/n, 08071 Barcelona, Spain
}

Received 14 October 2002; received in revised form 12 February 2003; accepted 13 March 2003

\begin{abstract}
We study the mechanics of lithospheric decoupling in continental extensional basins in relation to the distribution of (non-)competent mechanical layers within the lithosphere and the position of the isostatic compensation level. We specifically address the different modes of deformation taking place in crustal levels according to a self-consistent formulation of the concept of mechanical decoupling. Subsequently, we investigate the style of lithospheric decoupling in the Valencia Trough (NW Mediterranean), a prime example of a young continental rift basin. During its evolution, the lower crust (or at least part of it) acted as a weak, non-competent layer that eventually flowed laterally to accommodate deformation in the subcrustal lithosphere and overlying crust, which became mechanically decoupled. We use a numerical model to discern whether these two layers deformed fully independently (vertical decoupling), or maintaining a mechanical link (horizontal and partial decoupling). Results of our study, constrained by a high-quality database, exclude fully decoupled mode and favor isostatic compensation level in the asthenosphere. Interpretation of our results in light of geological and geophysical data suggests that the present Valencia Trough is best described by partial lithospheric decoupling.
\end{abstract}

(C) 2003 Elsevier Science B.V. All rights reserved.

Keywords: lithospheric decoupling; NW Mediterranean; numerical modelling; Valencia Trough

\section{Introduction}

Since the late seventies, several mechanisms have been proposed for intraplate deformation and the formation of sedimentary basins. Following initial models of pure shear [1] and simple

\footnotetext{
* Corresponding author. Tel.: +31-20-4447320; Fax: +31-20-4449943.

E-mail address: jorge.gaspar.escribano@falw.vu.nl (J.M. Gaspar-Escribano).
}

shear deformation [2], conceptual ideas have been developed and refined to address the complexities of the mechanisms involved in the final configuration of basins. These include regional flexure of the lithosphere [3], effects of horizontal stress fields [4], thermal processes and different rheological approaches [5] and process-oriented dynamical models [6].

Relatively simple models of basin formation (one-layer elastic, flexural approach, coupled with thermal field effects) have successfully explained the evolution of oceanic basins (e.g., 
$[3,7])$. In contrast, these models face difficulties in the case of continental lithosphere, requiring more assumptions (e.g., [5]).

The process of rifted basin formation implies consecutive stages of weakening of initially (moderately) strong lithosphere and lithospheric hardening after the cessation of the rifting cycle, due to the attenuation of the associated thermal anomaly. Also within the lithosphere, the upper crust, lower crust, lithospheric mantle, or any other individual, independent layer might respond in a different manner to the rifting process, depending on the initial geometry and rheological characteristics of the lithosphere and the rate of deformation (e.g., [8-10]). Such a mutually independent response of the various lithospheric layers is often referred as decoupling (e.g., [11]). However, different authors have significantly different views on the implications of this concept.

In this paper the issue of (de-)coupling of the lithosphere is addressed. In order to distinguish various interpretations of this concept, a more refined definition of it is proposed. To this aim, the mechanisms of formation of the Valencia Trough extensional basin (NW Mediterranean) are investigated using a numerical modeling approach.

\section{Lithospheric coupling and decoupling}

\subsection{Ductile lower crustal zone}

The traditional mechanical subdivision of the external part of the Earth distinguishes a rigid layer (lithosphere) overlying a weak, partially melted and low-viscosity layer (asthenosphere). For a given mineralogical structure of the upper mantle, the transition zone between these two layers is controlled by the position of the isotherms [12]. On tectonic time scales, the asthenosphere, subject to the weight of the overlying lithosphere (plate), deforms plastically, 'flowing' aside, in order to attain isostatic compensation of the lithospheric column.

In an analog rheological reasoning for continental crust, the occurrence of a mid-crustal transition zone in which crustal rocks change from a brittle to a ductile deformation mode has been proposed (e.g., [13]). At temperatures higher than $300-450^{\circ} \mathrm{C}$ (depending on the composition, strain rate and geotherm), normally corresponding to lower crustal levels, rocks attain such a low viscosity that can actually creep-flow [12]. According to the conventional rheological models, the uppermost mantle constitutes a strong, more rigid zone confining this flow to lower crustal levels. The general lack of deep crustal seismicity [14], the low seismic velocities found [15] and the bending of faults that flatten out at the top of this level, have been usually pointed as indicators of such a low-viscosity zone [16]. Additionally, some authors argue that the semi-horizontal, lower crustal strong seismic reflectors observed in many areas represent ductile shear bands, which denote actual horizontal mass-flow expected within the low-viscosity zone [17].

The three-layered (strong upper crust, soft lower crust and strong upper mantle) rheological model described above has been questioned recently (e.g., $[18,19])$. Based on analyses of the seismogenic layer in continents [20] and using gravity and topography data as constraints, these authors propose a rheological model in which the whole crust is the strongest lithospheric layer and the lithospheric mantle is relatively weak.

\subsection{Implications of a crustal decoupling level on the tectonic evolution of the lithospheric}

Given the thermal and rheological conditions sustaining a lower crustal low-viscosity zone, the implications for the tectonic evolution of the continental lithosphere are important (e.g., [5,21]). Basically, the existence of such a zone between the stronger bounding layers enables them to react in a different manner to deformation, and implies an overall lithospheric strength reduction. This is what causes 'decoupling' of the lithosphere, and the lower crustal low-viscosity zone is the 'decoupling level'. However, depending on the authors and the approach they have chosen the term decoupling has been given different meanings.

Some authors consider decoupling as the possibility of two (lithospheric) layers to move only laterally with respect to each other, interacting 
mechanically by shearing in the intermediate, weak layer (Fig. 1b; e.g. [22]), facilitating differential stretching. The lithosphere presents a rather low strength (or equivalently, low values of effective elastic thickness, $T_{\mathrm{e}}$ ) and the isostatic compensation level remains at the base of the lithosphere. This is what we will call in this paper horizontal decoupling.

Other authors have studied decoupling as the possibility of two layers to move independently of each other in the vertical sense (e.g. [23], see Fig. 1c). In this view, stresses exerted by the bounding brittle layers would not be transmitted vertically. In contrast, they would be dissipated in the low-viscosity layer, which would flow horizontally in order to compensate isostatic disequilibrium. We will refer to this mode as vertical decoupling. For this extreme situation for a continental extensional basin, it could be the case that, as lithosphere stretches, the upper crust could deform independently from the upper mantle.

More recently, ter Voorde et al. [24] and Waltham et al. [25] have proposed a partially decoupled mode of lithospheric deformation, which could be considered as a combination of horizontal and vertical decoupling. At first order approximation, the lithosphere is isostatically coupled. In this case, the viscosity of the lower crust is not low enough to produce significant lateral flow to accommodate all load unbalances. Only shortwavelength loads can be compensated in lower crustal levels, whereas long-wavelength loads are compensated in the asthenosphere.

The alternative rheological model with a weak mantle and a strong crust, with no distinction in terms of strength between upper and lower crust as proposed by Maggi et al. [18] and Jackson [19] explicitly considers that the lithosphere is not mechanically decoupled at lower crustal levels (Fig. 1a).

\subsection{Isostatic coupling versus isostatic decoupling}

Estimates on how the occurrence of a decoupling layer affects isostatic movements are obviously different depending on the concept that is used: each decoupling model locates the isostatic compensation level in a different place (astheno- a
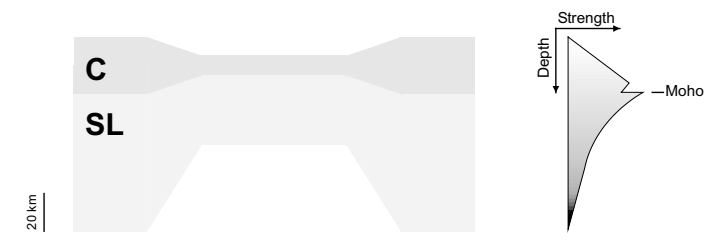

b

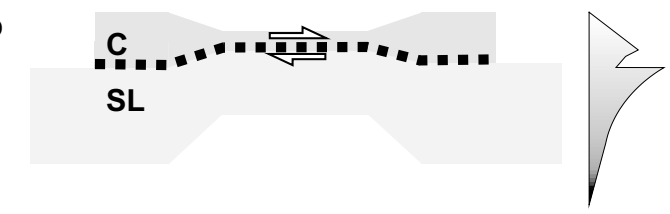

C

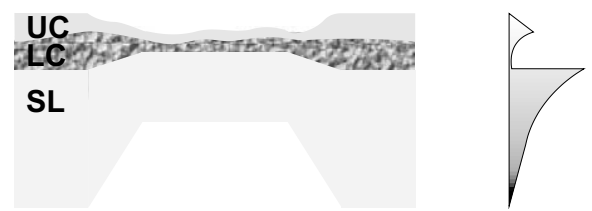

Fig. 1. Cartoon illustrating concepts of horizontal and vertical decoupling. Left: Geometry of the lithosphere. Dark and light gray represent crust and subcrustal lithosphere respectively. Right: Yield strength as a function of depth for brittle-ductile rheology of the lithosphere. C, crust; SL, subcrustal lithosphere; UC, upper crust; LC, lower crust. (a) Uniform stretching (fully lithospheric coupling). (b) Horizontal decoupling [22]. Thick dotted line and white arrows represent the level of relative shearing between the decoupled layers. (c) Vertical decoupling (after [23]).

sphere for horizontal decoupling and lower crust for total vertical decoupling). In this respect, when isostatic analysis is conducted, it can be appropriate to use the term isostatic coupling of the lithosphere when referring to a sublithospheric compensation level, and isostatic decoupling of the lithosphere when referring to a intralithospheric compensation level.

In an attempt to express with one parameter how the lithosphere would evolve in an extensional tectonic regime given a strength pattern, some researchers have introduced the concept of lithospheric necking. This is defined as the level that would remain horizontal as extension progresses in absence of isostatic forces [26,27], and it is related to the position of the strongest lithospheric layer(s) (more difficult to deform) at the beginning of the extension [28]. Thus, the level of necking is the bulk expression of a more detailed lithospher- 

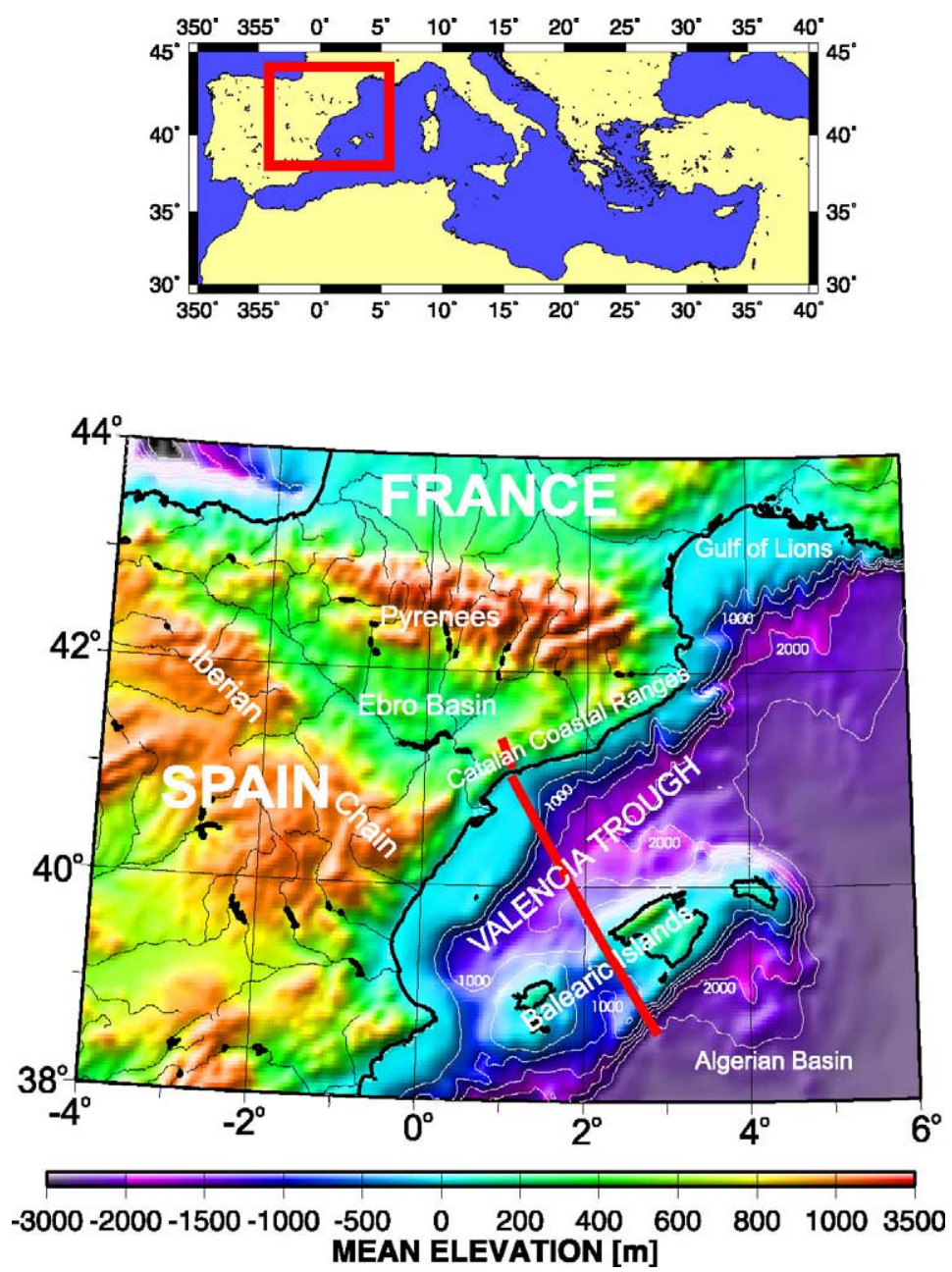

Fig. 2. Upper panel: Location of the study area offshore NE Spain, in the northwestern Mediterranean Sea. Lower panel: Topography and bathymetry map indicating location of ESCI-Catalan Valencia Trough deep seismic reflection profile.

ic mechanical structure, in which rheological properties (prior to and during rifting), relative position of detachment levels and strong/weak layers in the lithosphere, can lead to decoupling. So far, no one-to-one relationship between lithospheric decoupling and necking has been established, and both quantitative and qualitative valuations lack accuracy (e.g., [28]). However, from a modeling point of view, the depth of necking is a very useful parameter and illustrative when interpreted in light of geological and geophysical data.

In the following, the state of decoupling of the lithosphere in the Valencia Trough is investigated using a numerical model that accounts for isostasy, necking of the lithosphere, differential stretching and thermal effects. The high-quality geological and geophysical data set available in this area offers the framework to test the concepts discussed above.

\section{The Valencia Trough}

The Valencia Trough is a Neogene extensional basin located offshore northeastern Spain, in the 
northwestern Mediterranean (Fig. 2). Its axis is SW-NE oriented, and it is wider to the northeast (where it connects to the Liguro-Provençal Basin) than to the southwest. The Catalan Coastal Ranges and the Balearic Islands bound this basin to the northwest and southeast respectively. Its potential as an oil-producing area triggered many geophysical surveys that yielded a highquality database. Significant parts of these studies have been summarized and reviewed in [29-32].

The rift basin started to open during Late Oligocene over an inverted Mesozoic basin that was subjected to non-deposition and erosion during most of the Paleogene [33]. It appears that the opening was not synchronous all over the basin [34], but that rifting commenced earlier in the northeast (Late Oligocene; $28 \mathrm{Ma}$ ) than in the southwest (Early Miocene; $22 \mathrm{Ma}$ ). In our study area, the syn-rift stage, in which fault activity was important, can be dated as Late Oligocene-Early Miocene (25-16 Ma) and the subsequent post-rift stage, with generalized thermal subsidence, lasted until the present day [32].

The present-day Valencia Trough is largely asymmetrical. Bathymetry increases from southwest to northeast. The sedimentary infill of the basin is Late Oligocene to Quaternary in age $[35,36]$. Syn-rift sediments are preserved mainly in the troughs of the basin and constitute a moderate amount of the total infill. Although post-rift sequences are abundant, the basin is partly sediment-starved [31], being constantly infilled by material eroded mainly from the flanking ranges (Catalan Coastal Ranges and Iberian Chain) and transported by bounding river networks (mainly the Ebro River). In the southeastern margin, Late Oligocene-Middle Miocene compressional tectonics led to the development of a WNW-verging fold-and-thrust belt which involved Paleozoic basement, Mesozoic cover and Paleogene to Middle Miocene sediments [33].

The rifting process developed in continental lithosphere and did not lead to the formation of oceanic lithosphere. However, the crust as well as the whole lithosphere were extremely thinned $[30,37]$ and the thermal anomaly still remains significant, as demonstrated by the relatively high surface heat flow values measured [38].

\section{Lithospheric (de-)coupling in the Valencia Trough}

\subsection{ESCI-Catalan and Valencia Trough seismic line}

Our modeling is based on a deep seismic reflection profile that crosses the Valencia Trough from the Iberian Peninsula to the South Balearic Basin (ESCI-Catalan and Valencia Trough profiles, Fig. 3 ; [32]). This section is constrained by wide-angle data [39], boreholes [29], surface data and industrial seismic profiles $[32,40,41]$. It provides an excellent image of sedimentary packages filling the basin and of the crustal structure, with the exception of the axis of the basin.

A number of features from the seismic section (Fig. 3) are listed below. They are consistent with older data in other areas of the Valencia Trough [42-46], and therefore can be regarded as representative of the basin:

1. The crust dramatically thins from the Iberian margin towards the axis of the Valencia Trough, getting thicker again underneath the thrust sequences that form the Balearic Promontory. In some parts of the axial domain of the Valencia Trough, thinning is so severe that the lower crust might have disappeared [47] or be intruded by mantle rocks [48] as revealed by anomalous low mantle velocities and gravity models [45,49]. Thickening in the Balearic Promontory is due to thrust tectonics coeval with rifting $[32,33]$.

2. The lower crust is thinned in a higher degree than the upper crust (including the Mesozoic cover). This feature would confirm some degree of mechanical decoupling (horizontal following the convention established in Section 2) between upper and lower crust [32,40,50,51].

3 . Upper and lower crusts have markedly different reflectivity patterns. The upper crust is almost transparent whilst the lower crust is more reflective, showing manifest reflectivity variations along the profile. These observations would indicate a major rheological change between both crustal layers. Strong reflectors display lower crustal thinning from the Iberian mainland to the Valencia Trough [39]. Lower 

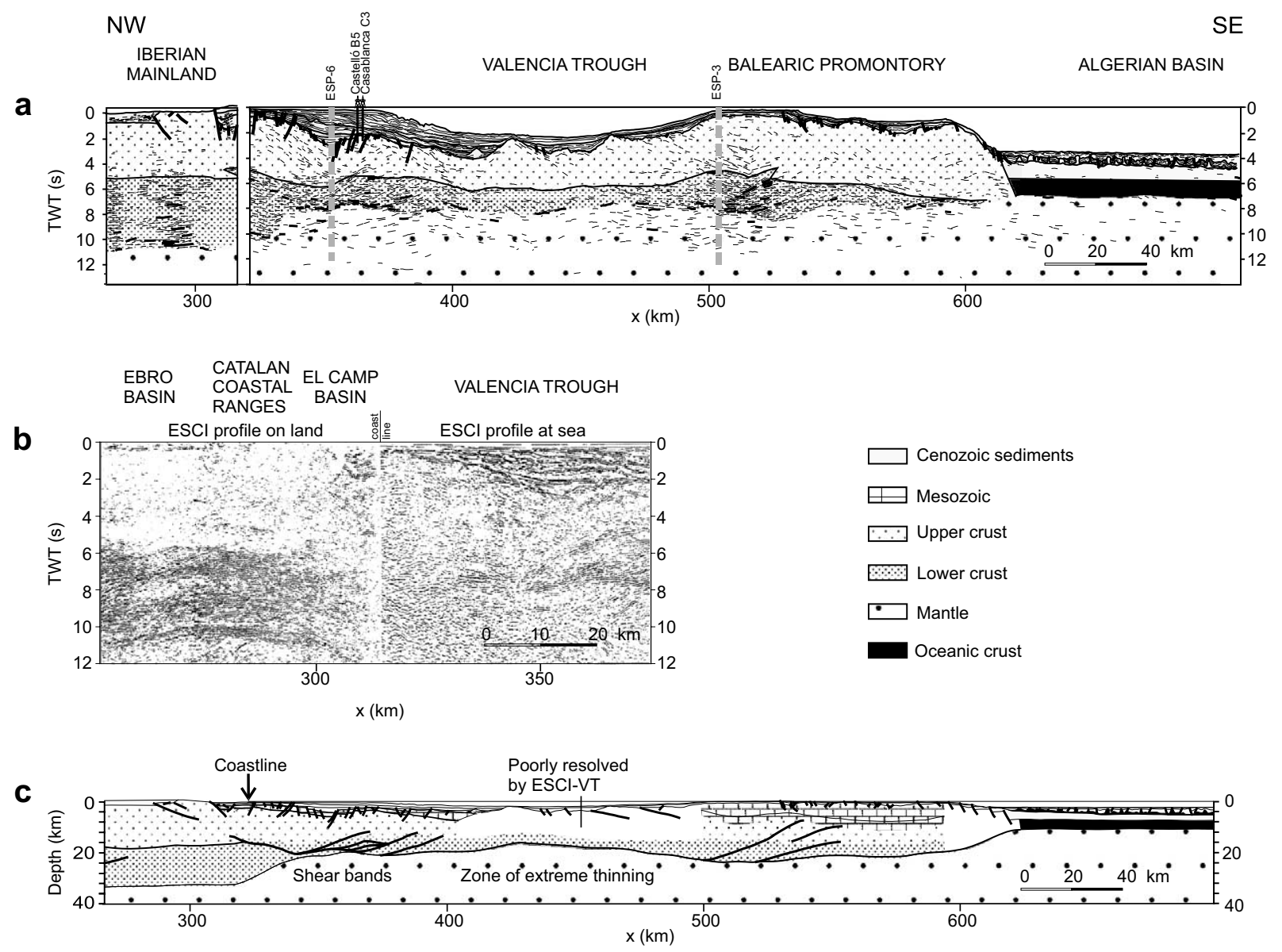

Fig. 3. ESCI-Catalan Valencia Trough seismic reflection profile [32]. (a) Two-way travel time interpreted line drawing and interpretation (after [40]). (b) Composite stacked section of the ESCI vertical reflection profiles on land and at sea [41]. (c) Depth conversion of the section according to Vidal et al. [39] and modified in the shallowest levels to precisely locate the base of Cenozoic sediments, as constrained from well data [29] and ESP data [44,45]. In this figure Mesozoic sediments and upper crust are differentiated. See text for further explanation.

crustal reflectivity diminishes (and eventually disappears) towards the center of the basin as a consequence of Late Oligocene-Early Miocene extension [46]. Beneath the Balearic Promontory, the lower crust partially recovers its reflective character.

4. Extensional faults are observed in the upper crust and not in the lower crust, indicating that the requirements (rheological properties) for brittle failure do not occur in the middlelower crust. This is also supported by the (moderate) seismicity in the area, which is re- stricted to upper crustal levels (focal depths $\leq 8 \mathrm{~km}$; [52]). These upper crustal faults are responsible for the formation of secondary sub-basins (El Camp Basin, Tarragona Basin), but cannot account for the opening of the whole Valencia Trough [53]. There is no evidence of fault continuation towards the center of the basin in deep levels [39]. Therefore considering a simple shear mechanism for the development of this rift basin [47] seems to be unrealistic [31,54].

5. The central part of the profile and the upper 
layers underneath the Balearic Promontory are not well constrained by the seismics. Comparison with studies carried out in adjacent domains within the Valencia Trough suggests that volcanic edifices could have been sited in crustal levels in the center of the basin, and perturbed the lithospheric rheological layering [50].

According to Sàbat et al. [40] the configuration of lower crustal strong reflectors in the transition from the stable Iberian crust to the Valencia Trough reveals the existence of shear bands that accommodated deformation during rifting. In the Balearic margin some (reverse) shear bands are observed in the lower crust as well [40]. These bands could be vestiges of lower crustal material flow.

\subsection{Additional data: vertical decoupling in the Valencia Trough as working hypothesis}

All the points described above have been used as evidence for crustal horizontal decoupling in the Valencia Trough by many authors [32,50,51,53]. Also, basin crustal-scale restorations [32,53] and evolutionary numerical models of the Valencia Trough $[51,55,56]$ implicitly assume a horizontal decoupling. In the models that incorporate isostasy the compensation level is located in the asthenosphere (i.e., isostatic coupling). Vertical decoupling has not been considered in this area, though.

The Valencia Trough consists of a thermally young lithosphere. Surface heat flow measurements give intermediate to relatively high values $\left(78 \pm 13 \mathrm{~mW} \mathrm{~m}^{-2}\right.$ in average, increasing locally up to $105 \mathrm{~mW} \mathrm{~m}^{-2}$; [38]), which are probably underestimated by $10-15 \%$ because they were not corrected by effects of recent sedimentation [49]. Numerical studies addressing the thermal structure of the lithosphere in the Valencia Trough constrain the range of expected lower crustal temperatures at present. Thermal modeling results by Fernàndez et al. [57] show Moho temperatures increasing from $400^{\circ} \mathrm{C}$ in the axis of the Valencia Trough to $600^{\circ} \mathrm{C}$ in the Catalan margin. Assuming a rheological stratification with a relatively weak diabase-diorite lower crust, Zeyen and Fernàndez [49] predict Moho temperatures varying from $350^{\circ} \mathrm{C}$ in the axis of the basin to more than $600^{\circ} \mathrm{C}$ in its flanks. Alternatively, Negredo et al. [51], whose model implicitly assumes horizontal decoupling between upper and lower crust, predict Moho temperatures for the present ranging between $450^{\circ} \mathrm{C}$ to more than $600^{\circ} \mathrm{C}$ in the flanks. These values were higher at the end of the rifting phase: over $550^{\circ} \mathrm{C}$ all along the Valencia Trough [51]. Strain rate values in the order of $10^{-15} \mathrm{~s}^{-1}$ have been estimated for this area $[28,55]$. At these relatively high temperatures and surface heat flow, the lower crust (or at least the hottest part of it) will deform in a ductile mode [13] and eventually will be able to flow; during the syn-rift phase all over the basin and in the post-rift phase in the margins. These surface heat flow measurements

Table 1

Model parameters

Initial thickness of the crust [62]

Initial thickness of the upper crust $[32,62]$

Initial thickness of the lithosphere [63]

Initiation of rifting [32]

Duration of rift phase [32]

Sediment density (grain density) (adapted from [55])

Crustal density (average) [55]

Upper crustal density (only for vertical decoupling) [55]

Compensating material density (idem) [55]

Density of the mantle [55]

Surface porosity (derived from $[35,60]$ )

Depth-porosity relation constant (derived from [35,60])

Temperature at the base of the lithosphere [24]

Thermal diffusivity [24]

Thermal expansion coefficient [24]

$32 \mathrm{~km}$
$16 \mathrm{~km}$
$100 \mathrm{~km}$
$25 \mathrm{Ma}$
$9 \mathrm{Myr}$
$2600 \mathrm{~kg} \mathrm{~m}^{-3}$
$2825 \mathrm{~kg} \mathrm{~m}^{-3}$
$2700 \mathrm{~kg} \mathrm{~m}^{-3}$
$2950 \mathrm{~kg} \mathrm{~m}^{-3}$
$3270 \mathrm{~kg} \mathrm{~m}^{-3}$
0.75
$0.55 \mathrm{~m}^{-1}$
$1330^{\circ} \mathrm{C}^{-7} \mathrm{~m}^{-2} \mathrm{~s}^{-1}$
$7.8 \times 10^{-7}$
$3.4 \times 10^{-5}{ }^{\circ} \mathrm{C}^{-1}$


and thermal structure estimates support the idea of vertical decoupling in lower crustal depths. The moderate value of the strain rate prevents any a priori consideration in this respect.

Below, we investigate the role of (isostatic) vertical decoupling in this region. Provided that all the evidence points to the existence of a crustal decoupling level, the question is: would the lower crust be able to flow aside and become the isostatic compensation level for flexural calculations?

\section{Numerical modeling}

\subsection{Modeling approach}

A numerical model that takes into account flexure of the lithosphere, lateral heat transport and lithospheric necking [58] is used. Basin subsidence and flank uplift are simulated by setting stretching factors and corrected for sea level oscillations (sea level curve from [59]) and sediment compaction effects (based on [60]). Other parameters are given in Table 1. Effective elastic thickness $\left(T_{\mathrm{e}}\right)$ and depth of lithospheric necking $\left(z_{\mathrm{n}}\right)$ are free parameters, adjusted to fit the observations.

Three cases are investigated:

1. Uniform stretching of the lithosphere. The lithosphere is fully coupled, deforming as a whole with no intermediate layering over a creepflowing asthenospheric compensating material. This was the conventional approach followed by Janssen et al. [56].

2. Horizontal decoupling between crust and lithospheric mantle (i.e., different stretching factors for crust and lithospheric mantle), and isostatic coupling with the compensation level located in the asthenosphere.

3. Fully vertical decoupling between crustal layers (uniform stretching of upper crust) and isostatic decoupling with a lower crustal compensation level.

The case of partial decoupling has not been tested because this would require an extra parameter (the degree of decoupling) that we are not able to constrain. Moreover, the predicted rift basin geometry resulting from a partially decoupled scenario is hard to distinguish from the

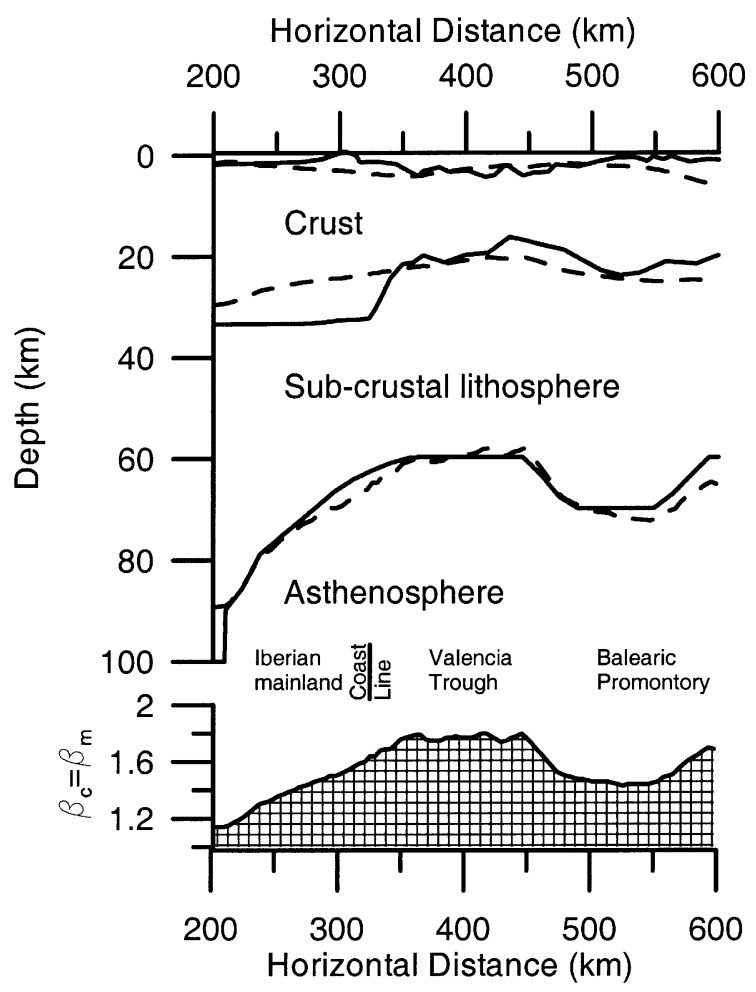

Fig. 4. Results for fully coupled case (uniform stretching; $\beta_{\mathrm{c}}=\beta_{\mathrm{m}}$; as in Fig. 1a). Upper panel shows lithospheric structure. Continuous lines represent observed horizons and dashed lines calculated horizons. Lower panel shows lithospheric thinning factors $\left(\beta_{\mathrm{c}}\right.$ and $\left.\beta_{\mathrm{m}}\right)$, derived by dividing prerift average lithospheric thickness (see Table 1) by presentday lithospheric thickness (taken from Fig. 3c and [37]).

one resulting from the isostatically coupled (horizontal decoupling) case [24].

\subsection{Modeling results}

The simplest case of complete lithospheric coupling (Fig. 4) gives a reasonable fit in those areas where the calculated horizons (i.e., base of Cenozoic sediments, base of the crust and base of the lithosphere) are smooth. In contrast, it fails to reproduce the shape of those horizons in areas of high gradient, as the transition from the Iberian crust to the Valencia Trough beneath the Catalan Coastal Ranges and the areas of extreme thinning in the center of the basin.

Fig. 5 displays results for the horizontal decoupling scenario. Despite some minor short-wave- 
length deviations, there is a good fit with observations. Best fit is obtained for low $T_{\mathrm{e}}$ values $(5$ $\mathrm{km})$ and intermediate depths of necking $\left(z_{\mathrm{n}}=15\right.$ $\mathrm{km})$. These values are in accordance with previous modeling studies predicting low rigidities [55,56], but situate the level of necking at shallower depths than Janssen et al. [56] (who proposed $z_{\mathrm{n}}$ values between 17 and $33 \mathrm{~km}$ ). These authors, who assumed uniform stretching of the whole lithosphere and ignored differential stretching of the subcrustal lithosphere, needed a deeper necking level in order to obtain substantial flank uplift fitting the topography of the CCR. In turn, as part of the topography of the CCR predicted in our model results from the onshore thinning of

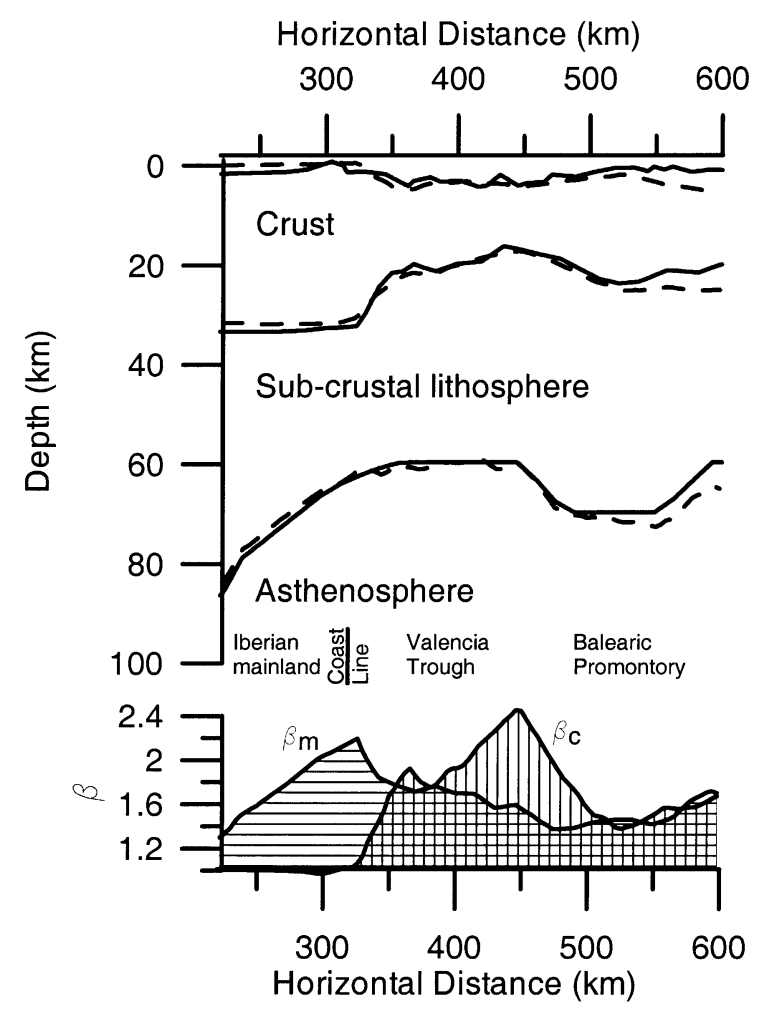

Fig. 5. Results for vertically coupled and horizontally decoupled case $\left(\beta_{\mathrm{c}} \neq \beta_{\mathrm{m}}\right.$; as in Fig. $\left.1 \mathrm{~b}\right)$. Upper panel shows lithospheric structure. Continuous lines represent observed horizons and dashed lines calculated horizons. Lower panel shows thinning factors $\left(\beta_{\mathrm{c}}\right.$ for the crust and $\beta_{\mathrm{m}}$ for the subcrustal lithosphere), derived by dividing pre-rift average crustal and subcrustal lithospheric thicknesses (see Table 1) by present-day crustal and subcrustal lithospheric thicknesses (taken from Fig. 3c and [37]).

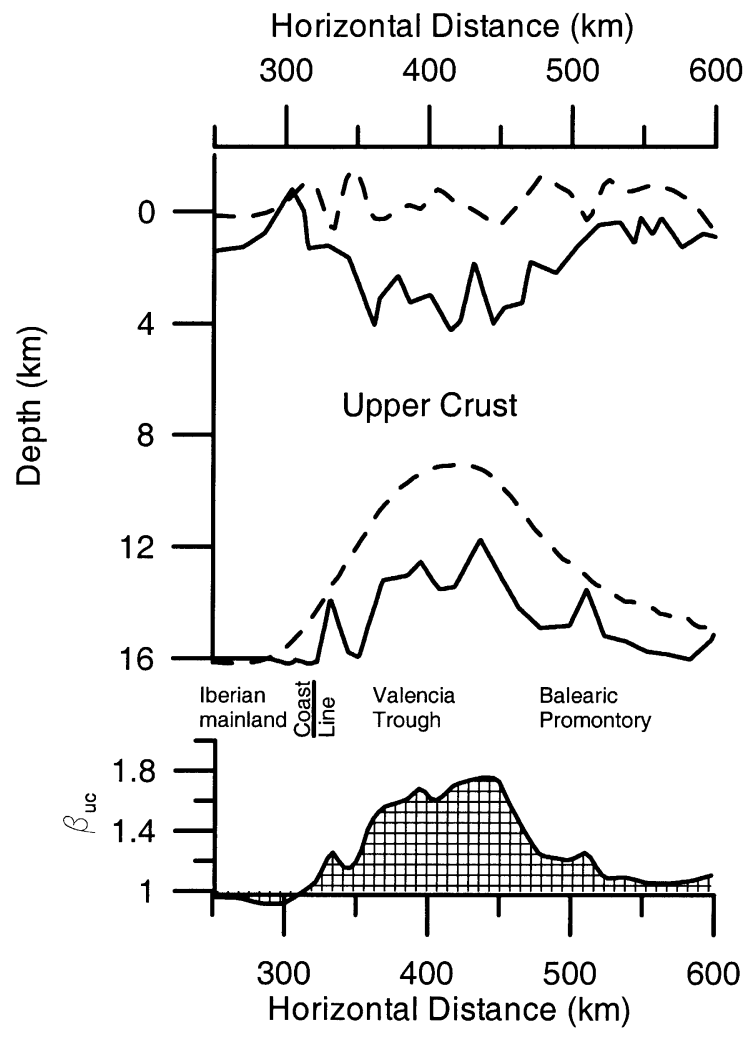

Fig. 6. Results for vertically and horizontally decoupled case (as in Fig. 1c). Upper panel shows lithospheric structure. Continuous lines represent observed horizons and dashed lines calculated horizons. Lower panel shows upper crustal thinning factors $\left(\beta_{\mathrm{uc}}\right)$, derived by dividing pre-rift average upper crustal thickness (see Table 1) by present-day upper crustal thickness (taken from Fig. 3c).

the subcrustal lithosphere, we do not require such a deep level of necking. Summarizing, our modeling predictions favor intermediate to shallow levels of necking instead of deep ones [61].

Here it is worth nothing that a similar horizontal decoupling model, but with the decoupling level located in mid-crustal levels (i.e., decoupling between upper crust and the rest of the lithosphere) was tested as well, yielding unsatisfactory results.

Results for vertical decoupling, focussing on upper crustal levels, are shown in Fig. 6. It is found that any reasonable combination of modeling parameters does not give a satisfactory result. There is always too little subsidence predicted, and in general upward buoyancy forces are 
more significant than downward loading forces. Due to the low density of the lower crust compared to the asthenosphere, (isostatic) total vertical decoupling does not cause enough flexural subsidence of the upper crust.

\subsection{Discussion}

The best fitting $T_{\mathrm{e}}$ value $(5 \mathrm{~km})$ found in our modeling corresponds to a low flexural rigidity $\left(D \approx 8 \times 10^{20} \mathrm{~N} \mathrm{~m}\right)$, that is associated to a weak lithosphere. Furthermore, the best fitting intermediate level of necking $\left(z_{\mathrm{n}}=15 \mathrm{~km}\right)$ denotes that the main contribution to the overall lithospheric strength is not rooted in the mantle. We relate this value with a strength maximum located in the base of the upper crust that controlled lithospheric deformation at the beginning of the rifting. This idea is supported by the fact that this level coincides with the depth of detachment in which master faults, controlling the opening of marginal sub-basins (Barcelona, Vallès-Penedès, El Camp, Tarragona), flatten out. That the depth of necking (indicative of the strength of the lithosphere at the initiation of the rifting) is lower than the $T_{\mathrm{e}}$ value (representative for the presentday strength of the lithosphere) reveals lithospheric weakening as a consequence of the rifting process. As lithospheric stretching progressed, the temperatures in lower crustal levels significantly increased [51]. This might have triggered lower crust flow leading to a vertical decoupling scenario. Post-rift thermal relaxation and intense thinning of the flow channel in the lower crust (both more pronounced in the axis of the basin) progressively destroyed this mechanism. This means that, at present, the viscosity of the lower crust is not low enough to prevent stress transmission between upper crust and subcrustal lithosphere, and the isostatic compensation level is located in the asthenosphere. This is confirmed by the fact that the model that best explains the present-day geometries is horizontal decoupling (and not vertical decoupling as could be interpreted from the low $T_{\mathrm{e}}$ value predicted).

Taking into consideration the geological and geophysical data as well as previous modeling studies, we interpret our modeling results as re- vealing that the Valencia Trough lithosphere responds to a partial decoupling deformation mode. In such a scenario, crust and subcrustal lithosphere are stretched to a different degree, the level of isostatic compensation for long-wavelength features is located in the asthenosphere and only short-wavelength features are compensated by (very limited) lower crustal flow. This last point could resolve the failure of the horizontal decoupling model to fit short-wavelength geometrical features (Fig. 5 and Section 5.2).

In contrast with recent studies contesting the 'jelly sandwich' rheological model [18,19], this study supports the occurrence of mechanical decoupling in the Valencia Trough.

\section{Conclusion}

The example of the Valencia Trough shows the necessity for unifying criteria when using the term (de-)coupling, specially in cases in which analyses of data and modeling results can be easily misinterpreted. At first sight, a number of observations suggest that the lithosphere in the Valencia Trough could have developed according to a fully isostatic vertical decoupling mode of deformation. Some predicted values for modeling parameters, such as the low $T_{\mathrm{e}}$ and the intermediate depth of necking, can be interpreted as consistent with this hypothesis. However, the model considering horizontal decoupling best fits the observed geometries. In order to integrate these observations and modeling results in a consistent manner, we suggest that the partially decoupled model, combining low flexural rigidities and sublithospheric isostatic compensation level, constitutes the best mechanical description of the Valencia Trough lithosphere at present.

\section{Acknowledgements}

We would like to thank G. Ranalli and D. Waltham for their constructive and critical reviews on the manuscript. This paper is publication number 2003.03.02 of the Netherlands Research School of Sedimentary Geology (NSG). We ac- 
knowledge funds by the Earth and Life Sciences (ALW) Council of the Netherlands Organization for Scientific Research (NWO), CICYT Project PB97-0882-C03 (subprojects 01 and 03), and the Research Group of Geodynamics and Basin Analysis (2001SGR00074) of Barcelona University. [AC]

\section{References}

[1] D. McKenzie, Some remarks on the development of sedimentary basins, Earth Planet. Sci. Lett. 40 (1978) 25-32.

[2] B. Wernicke, Uniform-sense normal simple shear of the continental lithosphere, Can. J. Earth Sci. 22 (1985) 108125.

[3] A.B. Watts, G.D. Karner, M.S. Steckler, Lithospheric flexure and evolution of sedimentary basins, Philos. Trans. R. Soc. London 305 (1982) 249-281.

[4] H. Kooi, S. Cloetingh, Lithospheric necking and regional isostasy at extensional basins 2 . Stress induced vertical motions and relative sea level changes, J. Geophys. Res. 97 (1992) 17573-17591.

[5] E. Burov, M. Diament, The effective elastic thickness $\left(\mathrm{T}_{\mathrm{e}}\right)$ of continental lithosphere: What does it really mean?, J. Geophys. Res. 100 (1995) 3905-3927.

[6] J.W. van Wijk, S.A.P.L. Cloetingh, Basin migration caused by slow lithospheric extension, Earth Planet. Sci. Lett. 198 (2002) 275-288.

[7] A. Cazenave, B. Lago, Rheological behavior of the oceanic lithosphere in response to loading, EOS Trans. 61 (1980) 381.

[8] N.L. Carter, M.C. Tsenn, Flow properties of continental lithosphere, Tectonophysics 136 (1987) 27-63.

[9] R.W. Buck, Modes of continental lithospheric extension, J. Geophys. Res. 96 (1991) 20161-20178.

[10] G. Bassi, Relative importance of strain rate and rheology for the mode of continental extension, J. Geophys. Int. 122 (1995) 195-210.

[11] J.R. Hopper, W.R. Buck, Styles of extensional decoupling, Geology 26 (1998) 699-702.

[12] R. Ranalli, Rheology of the Earth, Chapman\&Hall, London, 1995, $413 \mathrm{pp}$.

[13] N.J. Kusznir, R.G. Park, Continental lithosphere strength: the critical role of lower crustal deformation, in: J.B. Dawson, D.A. Carswell, J. Hall, K.H. Wedepohl (Eds.), The Nature of the Lower Continental Crust, Geol. Soc. Spec. Publ. No. 24, London, 1986, pp. 79-93.

[14] W.P. Chen, P. Molnar, Focal depths of intracontinental and intraplate earthquakes and their implications for the thermal and mechanical properties of the lithosphere, J. Geophys. Res. 88 (1983) 4183-4214.

[15] G. Ranalli, D.C. Murphy, Rheological stratification of the lithosphere, Tectonophysics 132 (1987) 281-295.

[16] B. Pinet, B. Colleta, Probing into extensional sedimentary basins: comparison of recent data and derivation of tentative models, Tectonophysics 173 (1990) 185-197.

[17] T.J. Reston, The lower crust and the extension of the continental lithosphere kinematics analysis of BIRPS deep seismic data, Tectonics 9 (1990) 1235-1248.

[18] A. Maggi, J.A. Jackson, D. McKenzie, K. Priestley, Earthquake focal depths, effective elastic thickness, and strength of the continental lithosphere, Geology 28 (2000) 495-498.

[19] J. Jackson, Strength of the continental lithosphere: time to abandon the jelly sandwich?, GSA Today 12 (2002) 4-10.

[20] A. Maggi, J.A. Jackson, K. Priestley, C. Baker, A re-assessment of focal depth distributions in southern Iran, the Tien Shan and northern India: do earthquakes really occur in the continental mantle?, Geophys. J. Int. 143 (2000) 629-661.

[21] L.I. Lobkovsky, V.I. Kercham, A two-level concept of plate tectonics: application to geodynamics, Tectonophysics 199 (1991) 343-374.

[22] J.R. Hopper, W.R. Buck, The effect of lower crustal flow on continental extension and passive margin formation, J. Geophys. Res. 101 (1996) 20175-20194.

[23] X. Le Pichon, N. Chamot-Rooke, Extension of continental crust, in: D.W. Muller, J.A. McKenzie, H. Weissert (Eds.), Controversies in Modern Geology, Academic Press, London, 1991, pp. 313-338.

[24] M. ter Voorde, R.T. van Balen, G. Bertotti, S.A.P.L. Cloetingh, The influence of a stratified rheology on the flexural response of the lithosphere to (un)loading by extensional faulting, Geophys. J. Int. 134 (1998) 721735 .

[25] D. Waltham, C. Docherty, C. Taberner, Decoupled flexure in the South Pyrenean foreland, J. Geophys. Res. 105 (2000) 16329-16340.

[26] J. Braun, C. Beaumont, A physical explanation of the relation between flank uplifts and the break-up unconformity at rifted continental margins, Geology 17 (1989) $760-764$.

[27] J.K. Weissel, G.D. Karner, Flexural uplift of rift flanks due to mechanical unloading of the lithosphere during extension, J. Geophys. Res. 94 (1989) 13919-13950.

[28] S. Cloetingh, J.D. van Wees, P.A. van der Beek, G. Spadini, Role of pre-rift rheology in kinematics of extensional basin formation: constraints from thermomechanical models of Mediterranean and intracratonic basins, Mar. Petrol. Geol. 12 (1995) 793-807.

[29] J.M. Lanaja, Contribución de la exploración petrolífera al conocimiento de la geología de España, Publ. I.G.M.E., Madrid, 1987, 465 pp.

[30] E. Banda, P. Santanach (Eds.), Geology and Geophysics of the Valencia Trough (Western Mediterranean), Tectonophysics Spec. Vol. 203, 1992, 361 pp.

[31] M. Torné, E. Banda, M. Fernàndez, The Valencia Trough: geological and geophysical constraints on basin formation models, in: P.A. Ziegler, F. Horvath (Eds.), Peri-Tethys Memoir 2: Structure and Prospects of Alpine 
Basins and Forelands, Mem. Mus. Natl. Hist. Nat. 170, Paris, 1996, pp. 103-128.

[32] E. Roca, The Northwest-Mediterranean basin (Valencia Trough, Gulf of Lions and Liguro-Provencal basins): structure and geodynamic evolution, in: P.A. Ziegler, W. Cavazza, A.F.H. Robertson (Eds.), Peri-Tethys Memoir, IGCP 369: Peri Tethyan Rift/Wrench Basins and Passive Margins, Mem. Mus. Natl. Hist. Nat., Paris, 2001, pp. 671-706.

[33] J.M. Fontboté, J. Guimerà, E. Roca, F. Sàbat, P. Santanach, F. Fernández-Ortigosa, The cenozoic evolution of the Valencia Trough (western Mediterranean), Rev. Soc. Geol. España 3 (1990) 249-259.

[34] E. Roca, M. Sans, L. Cabrera, M. Marzo, Oligocene to Middle Miocene evolution of the Central Catalan margin (North-western Mediterranean), Tectonophysics 315 (1999) 209-229.

[35] E. Clavell, X. Berástegui, Petroleum Geology of the Gulf of Valencia, in: A.M. Spencer (Ed.), Generation, Accumulation and Production of Europe's Hydrocarbons, Oxford University Press, Oxford, 1991, pp. 355-368.

[36] M.T. Bartrina, L. Cabrera, M.J. Jurado, J. Guimerà, E. Roca, Evolution of the central Catalan margin of the Valencia trough (western Mediterranean), Tectonophysics 203 (1992) 219-247.

[37] C. Ayala, J. Pous, M. Torné, The lithosphere-astenosphere boundary of the Valencia Trough (western Mediterranean) deduced from 2D geoid and gravity modelling, Geophys. Res. Lett. 23 (1996) 3131-3134.

[38] J.P. Foucher, A. Mauffret, M. Steckler, M.F. Brunet, A. Maillard, A. Rehault, B. Alonso, P. Desegaulx, J. Murillas, G. Ouillon, Heat flow in the Valencia Trough: geodynamic implications, Tectonophysics 203 (1992) 77-97.

[39] N. Vidal, J. Gallart, J.J. Dañobeitia, A deep seismic crustal transect from the NE Iberian Peninsula to the western Mediterranean, J. Geophys. Res. 103 (1998) 12381-12396.

[40] F. Sàbat, E. Roca, J.A. Muñoz, J. Vergés, P. Santanach, M. Sans, E. Masana, A. Estévez, C. Santisteban, Role of extension and compression in the evolution of the eastern margin of Iberia: the ESCI-Valencia Trough seismic profile, Rev. Soc. Geol. España 8 (1997) 431-448.

[41] J. Gallart, N. Vidal, A. Estévez, J. Pous, F. Sàbat, C. Santisteban, E. Suriñach, ESCI-Valencia Trough Working Group, The ESCI-Valencia Trough vertical reflection experiment: a seismic image of the crust from the NE Iberian Peninsula to the Western Mediterranean, Rev. Soc. Geol. España 8 (1997) 401-415.

[42] J. Gallart, N. Vidal, J.J. Dañobeitia, ESCI-Valencia Trough Working Group, Lateral variations in deep crustal structure at the Iberian margin of the Valencia trough imaged from seismic reflection methods, Tectonophysics 232 (1994) 59-75.

[43] J.J. Dañobeitia, M. Arguedas, J. Gallart, E. Banda, J. Markis, Deep crustal configuration of the Valencia Trough and its Iberian and Balearic borders from extensive refraction and wide-angle reflection profiling, Tectonophysics 203 (1992) 37-55.
[44] G. Pascal, M. Torné, P. Buhl, A.B. Watts, M. Mauffret, Crustal and velocity structure of the Valencia trough (western Mediterranean), Part II. Detailed interpretation of five Expanded Spread Profiles, Tectonophysics 203 (1992) 21-35.

[45] M. Torné, G. Pascal, P. Buhl, A.B. Watts, M. Mauffret, Crustal velocity and structure of the Valencia Trough (western Mediterranean), Part I. A combined refraction/ wide-angle reflection and near-vertical reflection study, Tectonophysics 203 (1992) 1-20.

[46] J.S. Collier, P. Buhl, M. Torné, A.B. Watts, Moho and lower crustal reflectivity beneath a young rift basin: results from a two-ship, wide aperture seismic reflection experiment in the Valencia Trough (western Mediterranean), Geophys. J. Int. 118 (1994) 159-180.

[47] J. Torres, C. Bois, J. Burrus, Initiation and evolution of the Valencia Trough (western Mediterranean): constraints from deep seismic profiling and subsidence analysis, Tectonophysics 228 (1993) 57-80.

[48] J. Martí, J. Mitjavila, E. Roca, A. Aparicio, Cenozoic magmatism of the Valencia Trough (western Mediterranean): relationship between structural evolution and volcanism, Tectonophysics 203 (1992) 145-165.

[49] H. Zeyen, M. Fernàndez, Integrated lithospheric modeling combining thermal, gravity and local isostasy analysis: Application to the NE Spanish geotransect, J. Geophys. Res. 99 (1994) 18089-18102.

[50] A. Maillard, A. Mauffret, Crustal structure and riftogenesis of the Valencia Trough (north-western Mediterranean Sea), Basin Res. 11 (1999) 357-359.

[51] A.M. Negredo, M. Fernàndez, M. Torné, C. Doglioni, Numerical modeling of simultaneous extension and compression: The Valencia Trough (western Mediterranean), Tectonics 18 (1999) 361-374.

[52] C. Olivera, T. Susagna, A. Roca, X. Goula, Seismicity of the Valencia Trough and surrounding areas, Tectonophysics 203 (1992) 99-109.

[53] J. Vergés, F. Sàbat, Constraints on the Neogene Mediterranean kinematic evolution along a $1000 \mathrm{~km}$ transect from Iberia to Africa, in: B. Durand, L. Jolivet, F. Horvath, M. Serrane (Eds.), The Mediterranean Basins: Tertiary Extension within the Alpine Orogen, Spec. Publ. Geol. Soc. 156, London, 1999, pp. 63-80.

[54] J.S. Collier, A.B. Watts, Seismic reflection constraints on lithospheric extension: pure versus simple shear, Geophys. J. Int. 129 (1997) 737-748.

[55] A.B. Watts, M. Torné, Subsidence history, crustal structure and thermal evolution of the Valencia Trough: a young extensional basin in the Western Mediterranean, J. Geophys. Res. 97 (1992) 20021-20041.

[56] M.E. Janssen, M. Torné, S. Cloetingh, E. Banda, Pliocene uplift of the eastern Iberian margin: Inferences from quantitative modelling of the Valencia Trough, Earth Planet. Sci. Lett. 119 (1993) 585-597.

[57] M. Fernàndez, M. Torné, H. Zeyen, Lithospheric thermal structure of NE Spain and the north-Balearic basin, J. Geodyn. 12 (1990) 253-267. 
[58] H. Kooi, S. Cloetingh, J. Burrus, Lithospheric necking and regional isostasy at extensional basins 1 . Subsidence and gravity modeling with application to the Gulf of Lions margin (SE France), J. Geophys. Res. 97 (1992) 17553-17571.

[59] B.U. Haq, J. Hardenbol, P.R. Vail, Chronology of fluctuating sea levels since the Triassic, Science 235 (1987) 1156-1167.

[60] J.G. Sclater, P.A.F. Christie, Continental Stretching: An explanation of the post-Mid-Cretaceous subsidence of the Central North Sea Basin, J. Geophys. Res. 85 (1980) 3711-3739.
[61] J.M. Gaspar-Escribano, J.D. Van Wees, M. Ter Voorde, S. Cloetingh, E. Roca, L. Cabrera, J.A. Muñoz, P.A. Ziegler, D. Garcia-Castellanos, 3D flexural modeling of the Ebro Basin (NE Iberia), Geophys. J. Int. 145 (2001) 349-367.

[62] E. Banda, Crustal parameters in the Iberian Peninsula, Phys. Earth Planet. Inter. 51 (1988) 222-225.

[63] N.A. Pino, D.V. Helmberger, Upper mantle compressional velocity structure beneath the West Mediterranean basin, J. Geophys. Res. 102 (1997) 2953-2967. 